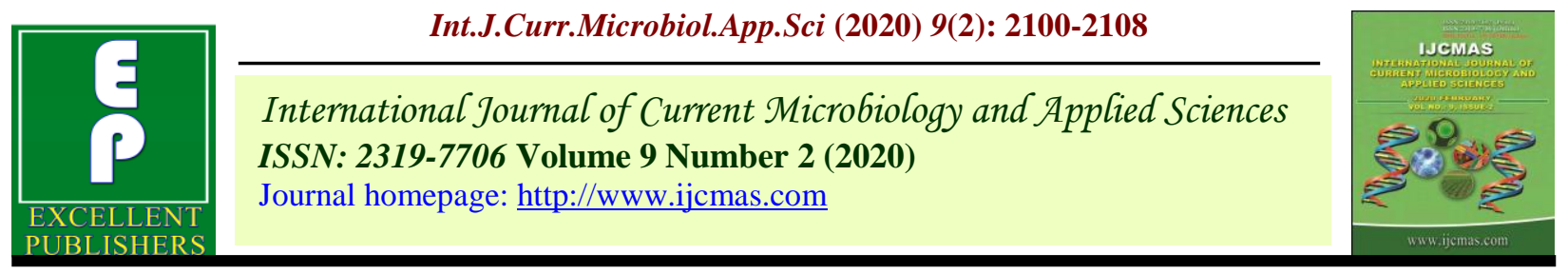

Original Research Article

https://doi.org/10.20546/ijcmas.2020.902.238

\title{
Evaluation of Seed Drill on Productivity and Resultant Seed Quality of Rainfed Horsegram
}

\author{
R. Thiyagarajan*' B. Suthakar and M. Manoharan \\ Department of Farm Machinery and Power Engineering, Agricultural Engineering College \\ and Research Institute, Tamil Nadu Agricultural University, Coimbatore-3, India \\ *Corresponding author
}

Keywords

Seed drill,

Horsegram, Cup feed, conventional method

Article Info

Accepted:

15 January 2020

Available Online:

10 February 2020

A B S T R A C T

Studies were conducted to evaluate the influence of seed drill sowing on productivity and resultant seed quality of rainfed horsegram at Regional Research Station, Paiyur, Krishnagiri district $\left(12.6257^{\circ} \mathrm{N}, 78.0195^{\circ} \mathrm{E}\right)$,Tamil Nadu. Horsegram cv.paiyur 2 was sown using cup feed seed drill modified with the cup size of $6 \mathrm{~mm}$, which was derived based on the major and minor axis of the seeds. The seed drill was compared with the conventional method of sowing. The field test conducted with the cup feed seed drill showed the average effective field capacity as 0.44 ha/h with 78.6 per cent field efficiency. The seed rate of 9.46 $\mathrm{kg} / \mathrm{ha}$ was registered for the cup feed seed drill. The results revealed that seed drill sown recorded 75 and 74 per cent increase in plant height, 41 and 29 per cent increase in number of leaves, 346 and 180 per cent increase in number of plants per square meter at important crop growth stages of 30 and 60 days after sowing when compared to broadcasting/ conventional method. The seed quality characters measured in terms of germination and vigour expressed a non-significant difference between the methods of sowing. The additional cost of operation using cup feed seed drill along with tractor is only Rs.1102/ha but it enhanced the cost benefit ratio to1:2.3 compared to broadcasting/conventional sowing (1:1.7) technique.

\section{Introduction}

Horse gram is one of the popular and most extensively grown pulse crop especially in Krishnagiri and Dharamapuri districts of Tamil Nadu having net sown area of 14502 ha and 8136 ha respectively. In Tamil Nadu a total area of 47,320 ha (Anon, 2012a) is under horse gram cultivation. Horse gram is an extremely drought resistant and dew loving crop which also serves as good animal fodder and as cover crop for preventing soil erosion in addition to potentiality to serve as green manuring. Horse gram grains are used as a human food, consumed after roasting or 
boiling and salted as well as cattle feed as a concentrated protein-rich feed especially for draft animals.

Sowing is one of the basic operations needed to get better revenue from agriculture. Manual sowing has the problem of labour availability and there is also uncertainty in depth of sowing. Sometimes seeds are even sown through broadcasting without the receipt of rain. The problem in broadcasting is lack of adequate spacing between row to row and plant to plant leading to lesser population of crops than that are recommended. Horse gram is a rainfed crop and mostly sown by broadcasting while line sowing is recommended to maintain the plant population and spacing.

In line sowing seeds are sown in rows and seeds in furrows are covered with soil drawn from adjacent furrows. In this method there is another problem of placing the seeds at correct depth and correct soil coverage and manual line sowing is time consuming and costly. Senapati et al., (1988) reported on the performance of six grain drills with lesser energy requirement, uniformity of seed distribution that resulted in enhanced crop yield. Heege (1993) evaluated four different planting methods of cereals, rape, and beans based on uniformity of planting depth and uniformity of seed distribution over the unit area and found that the precision drilling method had the best uniformity of planting depth and the broadcast-sowing method had the best uniformity of seed distribution per unit area.

Patel (2011) developed a power tiller operated five row multi crop seed drill which can be used for sowing paddy, green gram and black gram etc. he also reported that the machine is mounted at the back side of power tiller and can be easily attached and detached from power tiller. Flaps provided below the flutted rollers are kept in downward position while sowing paddy seed and are kept upward when machine is used for sowing smooth seeds. The machine was tested for sowing paddy, green gram and black gram. Metering ground wheel skidding was 24 percent. The field cap

acity of the machine was 0.15 ha $\mathrm{hr}^{-1}$. Ghosal and Pradhan (2013) evaluated a low cost manually operated multi crop seed drill with suitable dimensions of cup in cup feed metering mechanism and reported that there was a net savings of Rs. 1780 per hectare for green gram in comparison to the local traditional practice and total operating cost of Rs. 13.85 per hour would solve the problem of line sowing of seeds particularly for the small and marginal farmers to enhance production and productivity as a whole. To solve the above problems there is a need for development of an appropriate method for sowing the seeds.

Seed drill sowing had the advantage of faster coverage, timely sowing on receipt of rain, better placement of seed in optimum depth and economic utilization of labour. Hence studies were initiated to evaluate the efficacy of tractor drawn seed cup feed drill for sowing horse gram under rainfed condition at Regional Research Station, Paiyur.

\section{Materials and Methods}

In the present study, the existing cup feed seed drill used for multiple crops was taken for the evaluation with two different varieties released from Regional Research Station Paiyur viz., Paiyur 1 and Paiyur 2 highly suitable for rainfed sowing. The bulk seeds of horse gram were cleaned to remove foreign matter, broken and immature seeds. The calibration of the existing seed drill was done by operating the cup feed seed drill on plain ground surface covered with a plastic sheet to 
collect the horse gram seeds was metered by the machine. The horse gram Paiyur 2, the current ruling variety is taken and required quantity is filled in the respective hopper of the cup feed seed drill. The quantity of horse gram seeds per cup was recorded based on the unit length of forward travel.

As per the calculation it is observed that each cup picks around 9 to 13 numbers of seeds from the hopper and the same was dropped to the funnel for sowing. Based on the results of physical parameters for the horse gram cv. Paiyur 1 and Paiyur 2, cup diameter was reduced from 10 to $6 \mathrm{~mm}$ by applying the Mseal in the cup so as to use the same drill for horsegram.

After the modification of cup again the calibration is done to calculate the seed rate. From calibration, it is observed that each cup picks around 5-7 numbers of seeds from the hopper and it is calculated that around 11.07 $\mathrm{kg} \mathrm{ha}^{-1}$ of seed will be used for sowing in the field when using this modified cup feed seed drill, which was $9 \mathrm{~kg}$ lesser than actual recommended seed rate for sowing horse gram which is $20 \mathrm{~kg} \mathrm{ha}^{-1}$ (Anon, 2012b).

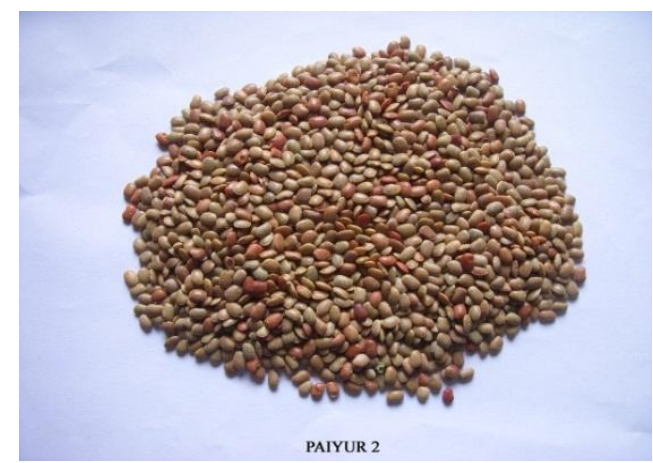

Figure.1 Horse gram variety Paiyur 2

During Kharif 2015, (October 2015), the horse gram paiyur 2 (Figure 1) was sown using the seed drill with modified cups along with conventional broadcasting. The crop was grown as rainfed crop and the meteorological data recorded during the crop growth period was presented in Table 1.

\section{Crop biometric observations}

During the crop growth and harvest, following crop biometric observations were observed in addition to the measurement on depth of placement of seeds under rainfed condition. The resultant seeds were also evaluated for seed germination and seed vigour. In the growing crop, at different crop growth stages viz., 30 and 60 days after sowing in one square meter block, the biometric observations on plant population, plant height $(\mathrm{mm})$, number of leaves per plant, grain yield per plot $^{-1}$ were observed as follows in thirteen different places.

\section{Measurement on depth of placement of seeds}

Depth of seed placement was measured by removing the plant from soil, and measuring the depth at which the seed was placed by removing the plant from soil in five different places and the mean expressed in millimeter.

\section{Resultant seed quality in terms of germination $(\%)$}

The germination test was conducted as per ISTA (2007) adopting roll towel (between paper) method using germination paper as medium. Four replicates of hundred seeds in each of the treatments were germinated as above under germination room condition maintained at $25 \pm 2^{\circ} \mathrm{C}$ temperature and $95 \pm 1 \% \mathrm{RH}$. After the germination period of six (horse gram) days (ISTA, 2007), the seedlings were evaluated as normal seedlings, abnormal seedlings, hard seeds and dead seeds as per ISTA. Based on normal seedlings the germination was calculated adopting the following formula and the mean expressed in percentage. 
Germination $(\%)=\frac{}{\text { Total number of seed sown }} \times 100$

\section{Root length \& shoot length (cm)}

The normal seedlings of the germination test in ten numbers from each of the replications were measured from collar region to the root tip is root length. The collar region to the shoot apex is said to be shoot length. Both the mean was expressed in millimeter.

\section{Dry matter production 10 seedlings $^{-1}(\mathrm{mg})$}

Ten normal seedlings selected for seedling measurements from each of the crops, treatments and replications were dried in shade for $24 \mathrm{~h}$ and were kept in an oven maintained at $85^{\circ} \mathrm{C}$ for $48 \mathrm{~h}$. After the drying period, the seedlings were cooled in closed desiccator over $\mathrm{CaCO}_{3}$ for $30 \mathrm{~min}$. and were weighed in a top pan balance and the mean expressed as dry matter production in milligram per 10 seedlings.

\section{Vigour index}

Vigour index values were computed using the following formula for each of the treatments and replications and the mean expressed as whole number (Abdul-Baki and Anderson, 1973).

Vigour index $=$ Germination $(\%)$ x Seedling length $(\mathrm{cm})$.

\section{Results and Discussion}

Evaluation of seed drill sowing for horsegram under rainfed condition

The seed drill with the modified cups was evaluated for its performance under field condition in an area of 0.15 ha with horsegram var.Paiyur2 (duration of crop is 105 days) prepared through conventional primary tillage in field No. 3 of F block of
Regional Research Station, Paiyur is shown in Figure 2. The furrow opener and the depth control were so adjusted to have a planting depth of 25-50 $\mathrm{mm}$.

The tractor was operated at speed of 2.0 to 3.0 $\mathrm{kmh}^{-1}$. The horse gram seeds were sown using the cup feed drill at row-to-row spacing of $250 \mathrm{~mm}$ and plant-to-plant spacing of $100 \mathrm{~mm}$ as rainfed horse gram crop. The view of field after sowing operation is shown in Figure 3.

For comparison, seeds were also sown in an area of 5 cents in the same field simultaneously adopting broad casting technique. The crop was grown as pure rainfed crop.

On evaluation of the performance of the cup feed seed drill, initially for the field parameters viz., the field capacity, field efficiency, seed rate and field emergence were observed, calculated and presented in the Table 2.

The field test conducted with the cup feed seed drill exposed the average effective field capacity as 0.44 ha $^{-1}$ with 78.6 per cent field efficiency. Plot size of one square meter was randomly selected from the field and measured the depth of sowing by removing the plant from soil in five different places. The values of depth of sowing of the seed drill were recorded. The average sowing depth in seed drill is $56.2 \pm 0.20 \mathrm{~mm}$.

\section{Crop Performance under rainfed condition}

At different crop growth stages viz., 30 and 60 days after sowing in one square meter block, the biometric observations on plant population, plant height $(\mathrm{mm})$, leaves per plant, grain yield was measured. The View of the horse gram field during 30 DAS \& 60 DAS are shown in Figure $4 \& 5$. Influence of seed drill sowing on growth and yield 
parameters is shown in Figure 6.

The results revealed that compared to broadcasting, seed drill sowing increased the plant height, leaves per plant and plants per square meter, pods per plant and the grain yield per sq.m, by $75 \& 74.2$ per cent at $30 \&$ 60 days, 29 per cent at 60 days, 352.4 Per cent at 60 days, 29.74 per cent and 22.86 per cent which might be due to the fact that placing the seeds in uniform depth increases the early germination and improved the yield. Increases in plant height, number of leaves per plant and number of plants per square meter might be due to the placing the seeds in uniform depth increase the early germination when compared with broadcasting

Table.1 The meteorological data under the crop period

\begin{tabular}{|c|c|c|c|c|}
\hline Duration (at Monthly intervals ) & \multicolumn{2}{|c|}{ Temp } & Rainfall, & RH, \% \\
\cline { 2 - 5 } & Max. & Min. & mm & \\
\hline October 2015 & 32.3 & 21.1 & 316.0 & 92 \\
\hline November 2015 & 27.5 & 21.1 & 535.4 & 92 \\
\hline December 2015 & 27.2 & 19.3 & 33.4 & 92 \\
\hline January 2016 & 29.3 & 16.3 & 0 & 86 \\
\hline February 2016 & 33.0 & 17.9 & 0 & 86 \\
\hline
\end{tabular}

Table.2 Field and machine characters on mechanical sowing

\begin{tabular}{|l|l|}
\hline \multicolumn{1}{|c|}{ Field and machine parameters } & \multicolumn{2}{c|}{ Values } \\
\hline Theoretical field capacity, C & $0.56 \mathrm{ha}_{\mathrm{hr}}^{-1}$ \\
\hline Effective field capacity, EFC & $0.44{\mathrm{ha} \cdot \mathrm{hr}^{-1}}^{-1}$ \\
\hline Field Efficiency (FE) & $78.6 \mathrm{per}$ cent \\
\hline Seeding Rate, SR & $9.46 \mathrm{~kg} / \mathrm{ha}$ \\
\hline Field emergence (\%) & $96 \mathrm{per} \mathrm{cent}$ \\
\hline
\end{tabular}

Table.3 Influence on type of sowing on resultant seed quality

\begin{tabular}{|l|c|c|c|c|}
\hline Parameters & Broadcasting & Machine sowing & SEd & CD (P=0.05) \\
\hline Germination (\%) & 96 & 96 & 0.002 & NS \\
\hline Root length(cm) & 15.9 & 16.4 & 0.003 & NS \\
\hline Shoot length(cm) & 13.6 & 13.4 & 0.012 & NS \\
\hline $\begin{array}{l}\text { Dry atter } \\
\text { production (mg) }\end{array}$ & 182 & 184 & 0.48 & NS \\
\hline Vigour index & 2832 & 2861 & 13.64 & NS \\
\hline
\end{tabular}




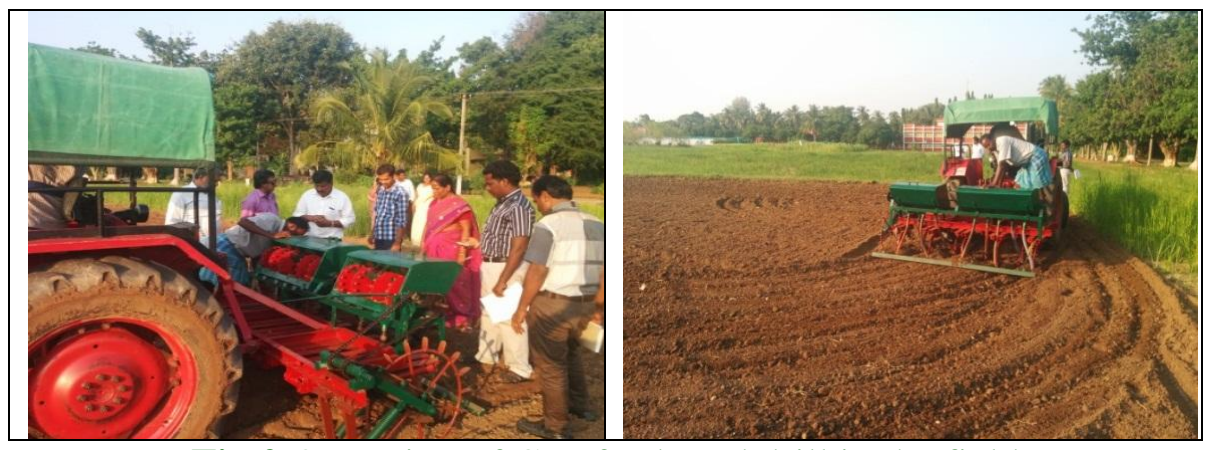

Fig.2 Operation of Cup feed seed drill in the field

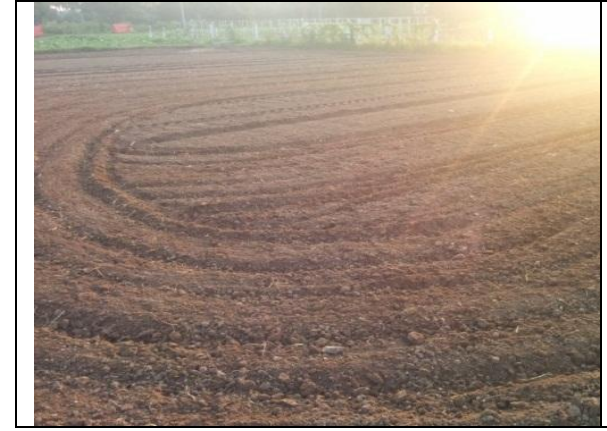

Seed drill sowing

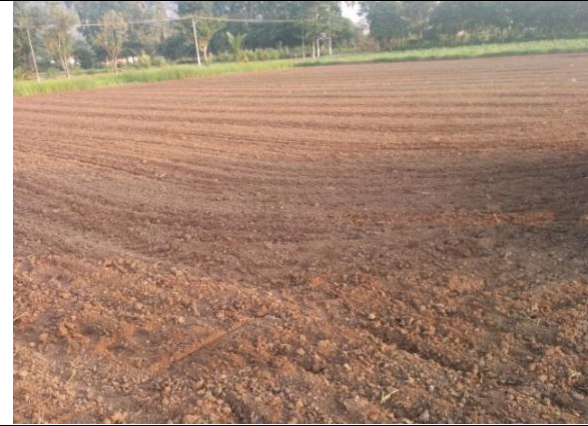

Broad casting

Fig.3 View of the field after sowing operation

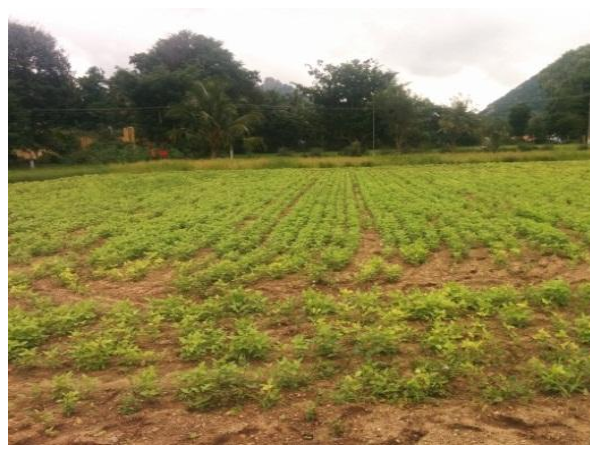

Seed drill sowing

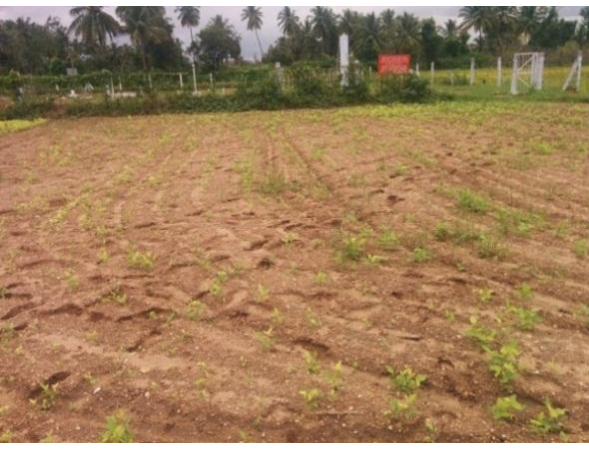

Broad casting

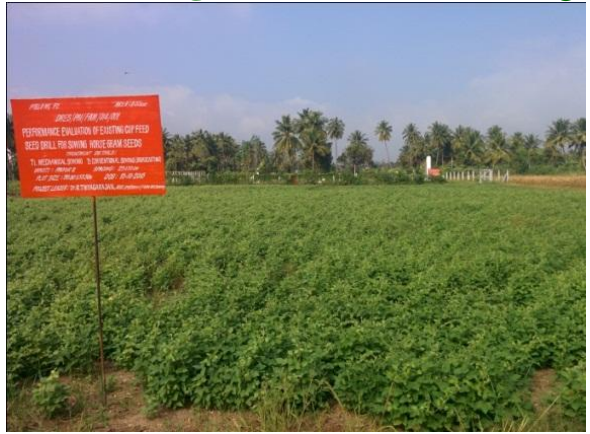

Seed drill sowing

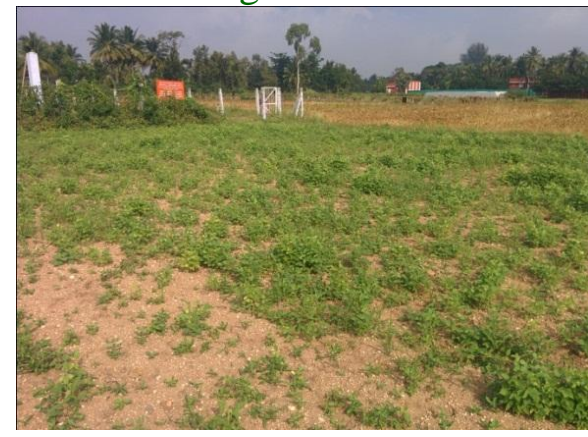

Broad casting

Fig.5 View of the horse gram field during 60 DAS 
Int.J.Curr.Microbiol.App.Sci (2020) 9(2): 2100-2108

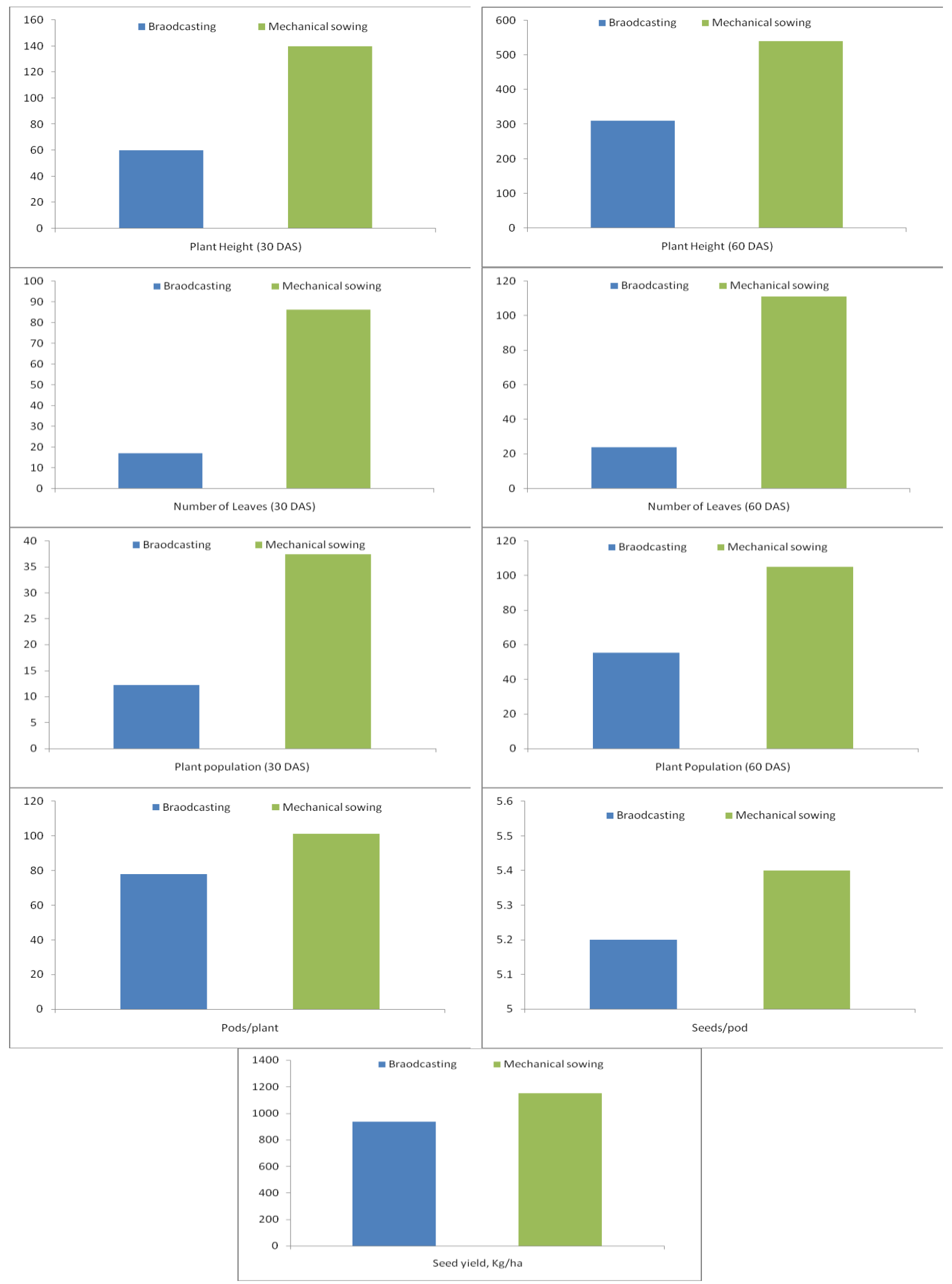

Fig.6 Influence of seed drill sowing on growth and yield parameters 
Mechanical sowing enhanced the crop yield by 23 per cent compared to broadcasting technique due to improvement in yield attributing characters and by the maintenance of plant population. Increases in yield might be due to fact that line sowing and maintaining the row spaces influenced the yield rate when compared with broad casting and placing the seeds in uniform depth at moisture influenced the crop yield.

\section{Resultant seed quality}

The results on seed quality characters expressed that in both the type sowing the seed quality characters were on par though mechanical sowing had reported slight higher seed quality characters (Table 3 ).

The results revealed that the difference between the types of sowing was insignificant and both the sowing types produced seeds with good quality

The performance of the tractor drawn cup feed seed drill was evaluated in actual field condition and compared to conventional broadcasting method.

The results revealed that seed drill sowing recorded 75 and 74 per cent increase in plant height, 41 and 29 per cent increase in number of leaves, 346 and 180 per cent increase in number of plants per square meter at important crop growth stages viz., 30 and 60 DAS when compared to control (broadcasting).

When sowing with the seed drill there was increase in number of pods per plant by 29 per cent, the crop yield by 23 per cent over control and there is no significant difference in seed drill sowing when compared to control for number of horse gram seeds pods ${ }^{-1}$. The average seed rate of the cup feed seed drill obtained in field was $9.46 \mathrm{~kg} / \mathrm{ha}$. The cost of operation of cup feed seed drill along with tractor is Rs.1102/ha. Benefit cost ratio of broad casting and machine sowing are 1:1.7 \& 1:2.3.

\section{References}

AbdulBaki, AA., Anderson, JD.,1973. Vigor determination in soybean by multiple criteria. Crop Science, 13, 630-633.

Anon 2012a, Seasonal Crop Report, Government of Tamil Nadu

Anon 2012b, Crop Protection guide, Tamil Nadu Agricultural University, Coimbatore

Anonymous, 2013, International rules for seed testing. Seed Sci. and Technol. 27, 27- 32.

Asoegwu, SN., Ohanyere, SO., Kanu, OP., Iwueke, CN., 2006. Physical properties of African oil bean seed (Pentaclethra macrophylla). Agricultural Engineering International: the CIGR E-journal VIII115.

Ghosal, MK., Pradhan, SC., 2013. Performance study of a low cost manually operated cup feed metering seed drill for sowing green gram. Agricultural Engineering Today. 37 (1), 37-41

Heege, HJ., 1993. Seeding methods performance for cereals, rape, and beans. Transactions of the ASAE 36(3): 653-661.

Olajide, JD., Igbeka, JC., 2003. Some physical properties of groundnut kernels. Journal of Food Engineering, 58, 201-204.

Panse, VG., Sukhatme PV., 1995. Statistical Methods for Agricultural Workers. ICAR, New Delhi.

Patel, SP., 2011.Development of power tiller operated seed drill for rice and pulse crop.An Oryza 48 (1): 52-55

Senapati, PC., Mohapatra, PK., Dikshit UN., 1992. Field evaluation of seeding devices for finger-millet. Agricultural Mechanization in Asia, Africa and Latin America. 23(3): 21-24. 


\section{How to cite this article:}

Thiyagarajan, R., B. Suthakar and Manoharan. M. 2020. Evaluation of Seed Drill on Productivity and Resultant Seed Quality of Rainfed Horsegram. Int.J.Curr.Microbiol.App.Sci. 9(02): 2100-2108. doi: https://doi.org/10.20546/ijcmas.2020.902.238 